\title{
Understory-overstory relationships in ponderosa pine forests, Black Hills, South Dakota
}

\author{
DANIEL W. URESK AND KIETH E. SEVERSON
}

\section{Abstract}

Understory-overstory relationships were examined over 7 different growing stock levels (GSLs) of 2 size classes (saplings, 8-10 cm d.b.h. and poles, 15-18 cm d.b.h.) of ponderosa pine (Pinus ponderosa) in the Black Hills, South Dakota. Generally, production of graminoids, forbs, and shrubs was similar between sapling and pole stands. Trends among GSLs were also similar between these tree size classes. Graminoids and forbs were most abundant in clearcuts and the $5 \mathrm{~m}^{2} / \mathrm{ha}$ basal area. Intermediate amounts were produced at GSLs of $14-23 \mathrm{~m}^{2} / \mathrm{ha}$ and lowest in unthinned stands which had basal areas ranging from $27-33 \mathrm{~m}^{2} / \mathrm{ha}$ and $37-40 \mathrm{~m}^{2} / \mathrm{ha}$ in sapling and pole stands, respectively. Total understory production followed the same trends. Shrubs, however, appeared to produce most at intermediate stocking levels but were variable. Graminoid and forb production were best estimated by the model $\log Y=a+b X$. Relationships for total production were better described by $Y=a+b X$. However, variability of shrub production precluded selection of a single model; the best model varied between tree size classes. Standard errors of the estimate indicate that reasonably good predictive models can be developed for pole and sapling stands considered separately or combined. When years were combined, however, SEs increased markedly, indicating less reliable models.

Key Words: plant production, forage, models, trees, basal area

Understory-overstory relationships have been extensively examined in ponderosa pine (Pinus ponderosa) stands throughout western North America (Ffolliott and Clary 1982). Generally, thinning dense pine stands yields multiple benefits. In the Black Hills, South Dakota, current estimates of timber production and animal unit months (AUM's) based on available herbage are 32.8 million cubic feet and 128,000 AUM's, (USDA Forest Service, nd). Proper management of ponderosa pine stands results in increased herbage for livestock and wildlife and increased wood production (Pase 1958, Clary and Ffolliott 1966, Jameson 1967, McConnell and Smith 1970, Clary 1975, Currie 1975, Bennett et al. 1987).

Published results of understory-overstory relationships in ponderosa pine forests are common. However, this study is unique for several reasons: (1) Other studies have not examined effects of tree size class on understory production. (2) All plots were on the same soil type on sites of roughly equal productivity. (3) Many other studies lacked replication in space and often covered only 1 year. (4) All stands, both sapling and pole, were about the same age, 70 years, when thinned. (5) Many previous studies centered on herbage production; shrub production often was ignored.

The objective of this study was to determine understory response to 7 different tree stocking levels (ranging from clearcuts to unthinned stands) of 2 size classes (poles and saplings) of ponderosa pine in the Black Hills.

\footnotetext{
Authors are respectively research biologist, Rocky Mountain Forest and Range Experiment Station, South Dakota School of Mines, Rapid City 57701; and range scientist, Rocky Mountain Forest and Range Experiment Station, Arizona State University, Tempe 85287.

Manuscript accepted 9 November 1988.
}

\section{Study Area}

The Black Hills of South Dakota and Wyoming are dominated by ponderosa pine. White spruce (Picea glauca), paper birch (Betula papyrifera), quaking aspen (Populus tremuloides), and bur oak (Quercus macrocarpa) are common associates (Boldt et al. 1983). Common understory species include bearberry (Arctostaphylos uva-ursi), common chokecherry (Prunus virginiana), Oregon grape (Berberis repens). Saskatoon serviceberry (Amelanchier alnifolia), and snowberry (Symphoricarpos spp.). Herbs include roughleaf ricegrass (Oryzopsis asperfolia), timber oatgrass (Danthonia intermedia), Kentucky bluegrass (Poa pratensis), cream peavine (Lathyrus ochroleucus), and bluebell (Campanula rotundifolia). Ponderosa pine and quaking aspen subtypes have been delineated by Thilenius (1972) and Severson and Thilenius (1976), respectively.

The study was conducted on the Black Hills Experimental Forest, about $30 \mathrm{~km}$ west of Rapid City, S.D. The Experimental Forest encompasses about 1,375 ha, with elevations ranging from $1,620-1,800 \mathrm{~m}$. Cattle grazed in a 3-pasture rotation system from mid-June through September each year. The Experimental Forest was part of a 3 pasture rotation and all pastures combined consisted of $2,834 \mathrm{ha}$. Stocking rate was $11 \mathrm{ha} / \mathrm{AUM}$ and grazing was confined to meadows. The average annual precipitation is $600 \mathrm{~mm}$, of which $70 \%$ falls from April to September. Growing season precipitation from 1 May to 31 July for 1974, 1976, 1981 was 168 mm, $325 \mathrm{~mm}, 348 \mathrm{~mm}$; and for previous year's precipitation; (1 August to 31 July) was $434 \mathrm{~m}, 1,196 \mathrm{~m}, 597 \mathrm{~m}$, respectively. Soils are primarily gray wooded, shallow to moderately deep, and derived from metamorphic rock (Boldt et al. 1983).

\section{Methods}

Seven growing stock levels (GSLs) of ponderosa pine plus an unthinned control were sampled. These were numerically designated as $0,5,9,14,18,23,28$, and unthinned. Growing stock indicates all living trees in a stand. The numerical designation of growing stock levels approximates, but does not necessarily equal, the actual basal area $\left(\mathrm{m}^{2} / \mathrm{ha}\right)$ of the stand. Basal areas of the unthinned pole stands ranged from $37-40 \mathrm{~m}^{2} /$ ha in 1981 , while unthinned sapling stands varied from $27-33 \mathrm{~m}^{2} / \mathrm{ha}$. Three replications of each of the 7 GSLs and unthinned controls were established in each of 2 size classes of pine: saplings $(7.6$ to $10.2 \mathrm{~cm}$ diameter at breast height [d.b.h.]) and small poles $(15.2-17.9 \mathrm{~cm}$ d.b.h.). These tree size classes are common and extensive in second-growth forests of the Black Hills.

The 3 replicated plots were selected randomly in areas with similar slopes and soils. Once plots were selected, they were thinned to the desired GSL from 5 to unthinned in 1963. Clearcut plots (0 GSL) were selected and treated in 1966. Cut stems were removed from all plots. Each of the square 24 plots in sapling stands was 0.10 ha in size, and each 24 in the pole stands was 0.20 ha. Miminal rethinning was required during winter 1973-1974 to maintain original GSLs.

Understory plants were allowed to respond a full decade before 
Table 1. Understory production (kg/ha) for 3 yaur in pole- and sapiling-aized ponderosa pine stands growing at different tree stocking levelh, Black Hills, South Dakota. Numbers are means t stand erron. * No Data.

\begin{tabular}{|c|c|c|c|c|c|c|c|c|c|}
\hline & \multirow[b]{2}{*}{ Year } & \multirow{2}{*}{$\begin{array}{c}\text { Clearcuts } \\
0\end{array}$} & \multicolumn{6}{|c|}{ Growing stocking levels ( $\mathrm{m}^{2} / \mathrm{ha}$ ) } & \multirow[b]{2}{*}{ Unthinned } \\
\hline & & & 5 & 9 & 14 & 18 & 23 & 28 & \\
\hline \multicolumn{10}{|l|}{ Pole Stands } \\
\hline Graminoids & $\begin{array}{l}74 \\
76 \\
81\end{array}$ & $\begin{array}{l}538 \pm 76 \\
633 \pm 30 \\
916 \pm 81\end{array}$ & $\begin{array}{l}193 \pm 45 \\
341 \pm 120 \\
484 \pm 63\end{array}$ & $\begin{array}{c}* \\
162 \pm 22\end{array}$ & $\begin{array}{r}48 \pm 15 \\
205 \pm 18 \\
113 \pm 26\end{array}$ & $114 \pm 46$ & $\begin{array}{l}32 \pm 17 \\
48 \pm 26 \\
61 \pm 30\end{array}$ & $35 \pm 14$ & $\begin{array}{r}5 \pm 4 \\
10 \pm 5 \\
4 \pm 3\end{array}$ \\
\hline Forbs & $\begin{array}{l}74 \\
76 \\
81\end{array}$ & $\begin{array}{l}161 \pm 15 \\
477 \pm 82 \\
385 \pm 11\end{array}$ & $\begin{array}{r}86 \pm 35 \\
164 \pm 36 \\
189 \pm 12\end{array}$ & $74 \pm 33$ & $\begin{array}{c}28 \pm 5 \\
73 \pm 31 \\
100 \pm 8\end{array}$ & $56 \pm 33$ & $\begin{array}{c}22 \pm 7 \\
27 \pm 8 \\
44 \pm 15\end{array}$ & $24 \pm 5$ & $\begin{array}{r}<1 \\
3 \pm 1 \\
6 \pm 3\end{array}$ \\
\hline Shrubs & $\begin{array}{l}74 \\
76 \\
81\end{array}$ & $\begin{array}{c}298 \pm 48 \\
821 \pm 220 \\
1344 \pm 43\end{array}$ & $\begin{array}{c}347 \pm 77 \\
1019 \pm 291 \\
945 \pm 116\end{array}$ & $1220 \pm 265$ & $\begin{array}{l}311 \pm 70 \\
948 \pm 279 \\
910 \pm 144\end{array}$ & $550 \pm 161$ & $\begin{array}{l}149 \pm 43 \\
681 \pm 155 \\
535 \pm 97\end{array}$ & $426 \pm 143$ & $\begin{array}{r}67 \pm 58 \\
100 \pm 94 \\
31 \pm 19\end{array}$ \\
\hline Total & $\begin{array}{l}74 \\
76 \\
81\end{array}$ & $\begin{array}{c}998 \pm 84 \\
1931 \pm 132 \\
2644 \pm 35\end{array}$ & $\begin{array}{c}626 \pm 46 \\
1523 \pm 252 \\
1620 \pm 86\end{array}$ & $1456 \pm 306$ & $\begin{array}{c}387 \pm 87 \\
1226 \pm 306 \\
1123 \pm 132\end{array}$ & $720 \pm 129$ & $\begin{array}{l}203 \pm 34 \\
756 \pm 127 \\
640 \pm 112\end{array}$ & $485 \pm 133$ & $\begin{array}{r}72 \pm 58 \\
113 \pm 96 \\
41 \pm 21\end{array}$ \\
\hline \multicolumn{10}{|l|}{ Sapling Stands } \\
\hline Graminoids & $\begin{array}{l}74 \\
76 \\
81\end{array}$ & $\begin{array}{r}676 \pm 100 \\
876 \pm 247 \\
1297 \pm 263\end{array}$ & $\begin{array}{c}806 \pm 231 \\
796 \pm 81 \\
1089 \pm 142\end{array}$ & $340 \pm 79$ & $\begin{array}{l}212 \pm 91 \\
454 \pm 187 \\
424 \pm 177\end{array}$ & $216 \pm 74$ & $\begin{array}{r}81 \pm 41 \\
127 \pm 18 \\
118 \pm 15\end{array}$ & $39 \pm 10$ & $\begin{array}{l}36 \pm 4 \\
57 \pm 24 \\
79 \pm 35\end{array}$ \\
\hline Forbs & $\begin{array}{l}74 \\
76 \\
81\end{array}$ & $\begin{array}{l}134 \pm 39 \\
296 \pm 33 \\
369 \pm 99\end{array}$ & $\begin{array}{l}102 \pm 16 \\
246 \pm 38 \\
276 \pm 6\end{array}$ & $306 \pm 86$ & $\begin{array}{c}37 \pm 14 \\
64 \pm 16 \\
117 \pm 52\end{array}$ & $59 \pm 16$ & $\begin{array}{l}34 \pm 22 \\
43 \pm 11 \\
92 \pm 10\end{array}$ & $19 \pm 8$ & $\begin{array}{c}8 \pm 4 \\
15 \pm 9 \\
26 \pm 16\end{array}$ \\
\hline Shrubs & $\begin{array}{l}74 \\
76 \\
81\end{array}$ & $\begin{array}{l}303 \pm 108 \\
964 \pm 411 \\
801 \pm 307\end{array}$ & $\begin{array}{c}244 \pm 57 \\
1156 \pm 54 \\
915 \pm 126\end{array}$ & $1255 \pm 233$ & $\begin{array}{l}308 \pm 76 \\
778 \pm 331 \\
935 \pm 428\end{array}$ & $1267 \pm 178$ & $\begin{array}{l}305 \pm 20 \\
597 \pm 330 \\
866 \pm 326\end{array}$ & $791 \pm 329$ & $\begin{array}{c}54 \pm 6 \\
269 \pm 111 \\
230 \pm 107\end{array}$ \\
\hline Total & $\begin{array}{l}74 \\
76 \\
81 \\
\end{array}$ & $\begin{array}{l}1113 \pm 115 \\
2126 \pm 196 \\
2450 \pm 168\end{array}$ & $\begin{array}{l}1152 \pm 196 \\
2199 \pm 70 \\
2280 \pm 102\end{array}$ & $1901 \pm 280$ & $\begin{array}{r}557 \pm 138 \\
1296 \pm 428 \\
1478 \pm 596\end{array}$ & $1542 \pm 113$ & $\begin{array}{c}420 \pm 57 \\
767 \pm 327 \\
1076 \pm 330 \\
\end{array}$ & $850 \pm 342$ & $\begin{array}{c}98 \pm 11 \\
341 \pm 138 \\
334 \pm 146\end{array}$ \\
\hline
\end{tabular}

measuring. Production of understory vegetation was measured by harvesting during August 1974, 1976, and 1981, on six 15-m, randomly placed line transects per plot. A total of twelve $30-$ by 61 -cm quadrats were randomly located along the transects in 1974 and 1976. These data indicated that an increase in number of quadrats would provide a better estimate of minor plant species. Therefore, in 1981 , twenty-five $0.125-\mathrm{m}^{2}$ circular plots were systematically located along 5 of the transects. All herbage was harvested by species to ground level, and current annual growth of all shrubs was removed by species, oven-dried, and weighed. Weights were averaged and expressed as mean per site for data analyses.

Numbers of species recorded from harvesting within each vegetation class among growing stock levels were tested with a 2-way (years by GSL) analysis of variance $(P=0.05)$. In cases with a significant $F$ value, means were separated using the Least Significant Differences method (Milliken and Johnson 1984).

Four regression models using plot means were used to test relationships between ponderosa pine overstory (the independent variable ( $x$ ) measured as $m^{2} /$ ha basal area) and current annual growth of the understory (the dependent variable ( $y$ ) measured as $\mathrm{kg} / \mathrm{ha}$ ). These models were: $y=a+b x, y=a x^{b}, y=e^{a+b x}$ (i.e., $\log Y=a+b x$ ), and $1 / y=a+b x$ (Statistical Graphics Corp. 1986). Further attempts were made to fit more complicated nonlinear models to selected data sets, but no improvement in goodness of fit was obtained. Basal area data for each individual plot were collected by C.E. Boldt and are on file at the Rocky Mountain Forest and Range Experiment Station, Rapid City, So. Dak., and Fort Collins, Colo.

Homogeneity of slopes (b) was tested with Student's $t$. If the assumption that slopes were homogeneous was met, homogeneity of intercepts of (a) was tested (Graybill 1976).

\section{Results}

\section{Understory Production \\ Pole-sized Stands}

Production of most forage classes varied among growing stock levels (GSLs) for both sapling- and pole-sized stands in all years (Table 1). In pole-sized ponderosa pine stands, grasses and carices generally produced the most in stands stocked at basal areas of 0 and $5 \mathrm{~m}^{2} /$ ha, intermediate amounts in those stocked from 9 to 18 $\mathrm{m}^{2} / \mathrm{ha}$, and the least in GSLs exceeding $23 \mathrm{~m}^{2} / \mathrm{ha}$. The number of graminoid species declined significantly; fewer were found in GSLs exceeding $14 \mathrm{~m}^{2} /$ ha than in the lower GSLs (Table 2). Timber oatgrass was the most abundant graminoid species under pole

Table 2. Number of epecies by vegetation class in pole- and sapling-dized ponderosa pine atands zrowing at different stocking levels, Black Hills, South Dakota.

\begin{tabular}{|c|c|c|c|c|c|c|c|c|}
\hline & \multicolumn{8}{|c|}{ Stocking level $\left(\mathrm{m}^{2} / \mathrm{ha}\right)$} \\
\hline & 0 & 5 & 9 & 14 & 18 & 23 & 28 & UT \\
\hline $\begin{array}{l}\text { Graminoids } \\
\text { Forbs } \\
\text { Shrubs }\end{array}$ & $\begin{array}{r}11 a^{2} \\
21 a \\
8 a \\
\end{array}$ & $\begin{array}{r}10 a \\
18 a \\
8 a \\
\end{array}$ & $\begin{array}{c}93 \\
12 \\
6 \\
\end{array}$ & $\begin{array}{c}\text { Pole } \\
5 b \\
12 b \\
5 b\end{array}$ & $\begin{array}{r}\text { tand } \\
63 \\
14 \\
6\end{array}$ & $\begin{array}{c}5 b \\
13 b \\
6 a b\end{array}$ & $\begin{array}{l}53 \\
9 \\
4\end{array}$ & $\begin{array}{l}3 b \\
5 c \\
4 b\end{array}$ \\
\hline Total & $40 a$ & 36 & 27 & $22 b$ & 26 & $24 b$ & 18 & $12 c$ \\
\hline $\begin{array}{l}\text { Graminoids } \\
\text { Forbs } \\
\text { Shrubs }\end{array}$ & $\begin{array}{r}9 a \\
18 a \\
7 a \\
\end{array}$ & $\begin{array}{r}9 a \\
15 b \\
6 a \\
\end{array}$ & $\begin{array}{r}7 \\
16 \\
8 \\
\end{array}$ & $\begin{array}{c}\text { Sapling } \\
9 \mathrm{a} \\
13 \mathrm{bc} \\
6 \mathrm{a} \\
\end{array}$ & $\begin{array}{c}\text { Stan } \\
7 \\
9 \\
6 \\
\end{array}$ & $\begin{array}{c}6 b \\
13 b c \\
8 a \\
\end{array}$ & $\begin{array}{l}4 \\
6 \\
5 \\
\end{array}$ & $\begin{array}{r}5 b \\
11 \mathrm{c} \\
7 \mathrm{a} \\
\end{array}$ \\
\hline Total & $34 a$ & $30 \mathrm{ab}$ & 31 & $\mathbf{2 8 b}$ & 22 & $27 b c$ & 15 & $23 c$ \\
\hline
\end{tabular}

IUnthinned

2Numbers followed by same letter in rows are not sionificantly different $(P>0.05)$. 39,18 , and 28 stocking levels not included in analysis, because they are represented by only $\mathbf{I}$ year's data. 
stands in all stocking levels, accounting for 49 to $91 \%$ of the total graminoid production. The only exception to this was in unthinned stands where it produced from 0-40\%. Bearded wheatgrass (Agropyron subsecundum) and sedges (Carex spp.) were common under the 2 lowest stocking levels, contributing 8 to $29 \%$; bearded wheatgrass was absent in GSLs greater than $9 \mathrm{~m}^{2} /$ ha. Sedges were unpredictable, declining in mid-levels ( 2 to $6 \%$ ), increasing again at $23 \mathrm{~m}^{2} / \mathrm{ha}$ ( 13 to $31 \%$ ), then declining to a trace in unthinned stands. Roughleaf ricegrass was nearly absent under pole-sized trees $(0$ to $11 \%$ ), but produced from 40 to $80 \%$ of the graminoid crop in unthinned stands.

Forb production in pole stands followed a similar pattern. Production was highest in the 2 lowest GSLs, intermediate from 9-23 $\mathrm{m}^{2}$ / ha, and lowest when basal areas were above $28 \mathrm{~m}^{2} /$ ha (Table 1). The number of forb species followed the same pattern (Table 2). There were no clear forb dominants in the lowest stocking levels; western yarrow (Achillea lanulosa), bluebell, cream peavine, and clovers (Trifolium spp.) were the most prevalent. At higher ponderosa pine stocking levels, from $9-28 \mathrm{~m}^{2} / \mathrm{ha}$, cream peavine accounted for almost half ( 37 to $63 \%$ ) the forb production. Few forbs were produced under unthinned stands.

Shrub production under pole-sized trees varied within stands, among GSLs, and years (Table 1). Shrub species in the 2 lowest stocking levels were greater than in all the others except the 23 $\mathrm{m}^{2}$ / ha GSL (Table 2). Despite the number of shrub species present, only 1 made a significant contribution-bearberry made up 70 to
99\% of the shrub production across all stocking levels.

Trends for total understory production under pole-sized ponderosa pine stands were lower in 1974 than in 1976 or 1981 in all GSLs except unthinned stands (Table 1). Generally, clearcuts in pole stands produced significantly more forage than other GSLs, except during 1974. Intermediate amounts were produced at GSLs 5 to 18 $\mathrm{m}^{2} / \mathrm{ha}$; less from GSLs of 9 to 28 ; and the least forage was produced under GSLs greater than $18 \mathrm{~m}^{2} /$ ha.

\section{Sapling-sized Stands}

As in pole-sized stands, bearded wheatgrass and sedges in sapling stands were common in the lower 2 GSLs representing 30 to $69 \%$ of the total graminoid production. Also, as in pole-sized stands, bearded wheatgrass was absent at GSL above $9 \mathrm{~m}^{2} / \mathrm{ha}$. Sedges fluctuated, declining at mid-levels (11 to $13 \%$ ), increasing at the upper-managed levels (22 to 32\%), and declining in unthinned stands (11 to 19\%). Timber oatgrass, the dominant understory grass in pole stands, represented an insignificant proportion of graminoid production in most sapling-sized pine stands (3 to 14\%). Roughleaf ricegrass made a small contribution to graminoid production in clearcuts ( 8 to $21 \%$ ) but produced more than one-third (36 to 39\%) of that in stands stocked with pine at $9 \mathrm{~m}^{2} /$ ha and dominated graminoids in GSLs above $14 \mathrm{~m}^{2} /$ ha ( 54 to $83 \%$ ). Total graminoid production in sapling stands was generally similar to pole stands (except in 1974). The number of graminoid species in GSLs 0 to $14 \mathrm{~m}^{2} /$ ha was significantly greater than in the higher GSLs (Table 2).

Table 3. Coeficients (a and b), standard error of the estimate (SE), mean of dependent variables ( relationships between understory production by vegetation class (Y) and ponderosa pine basal area (X)in pole- and sapling-sized stands for 3 years in the Black Hills, South Dakota.

\begin{tabular}{|c|c|c|c|c|c|c|c|c|}
\hline Stand & Year & $n^{1}$ & a & b & SE & $\overline{\bar{Y}}$ & $R^{2}$ & Type? \\
\hline & \multicolumn{8}{|c|}{ Graminoids } \\
\hline Pole & $\begin{array}{l}74 \\
76 \\
81\end{array}$ & $\begin{array}{l}15 \\
24 \\
15\end{array}$ & $\begin{array}{l}5.994 \mathrm{a}^{3} \\
6.517 \mathrm{a} \\
7.088 \mathrm{~b}\end{array}$ & $\begin{array}{l}-0.160 \mathrm{a}^{3} \\
-0.133 \mathrm{a} \\
-0.158 \mathrm{a}\end{array}$ & $\begin{array}{r}87.7^{5} \\
88.5 \\
157.3\end{array}$ & $\begin{array}{l}163.1 \\
193.4 \\
315.6\end{array}$ & $\begin{array}{l}75.3 \\
73.6 \\
83.7\end{array}$ & $\begin{array}{l}\mathbf{E} \\
\mathbf{E} \\
\mathbf{E}\end{array}$ \\
\hline Sapling & $\begin{array}{l}74 \\
76 \\
81\end{array}$ & $\begin{array}{l}15 \\
24 \\
15\end{array}$ & $\begin{array}{l}6.463 \mathrm{a} \\
6.765 \mathrm{a} \\
7.251 \mathrm{~b}\end{array}$ & $\begin{array}{l}-0.123 a \\
-0.124 a \\
-0.113 a\end{array}$ & $\begin{array}{l}245.0 \\
213.0 \\
286.6\end{array}$ & $\begin{array}{l}362.3 \\
362.3 \\
597.7\end{array}$ & $\begin{array}{l}72.4 \\
64.5 \\
74.5\end{array}$ & $\begin{array}{l}\mathbf{E} \\
\mathbf{E} \\
\mathbf{E}\end{array}$ \\
\hline Pole & $\begin{array}{l}74 \\
76 \\
81\end{array}$ & $\begin{array}{l}15 \\
24 \\
15\end{array}$ & $\begin{array}{l}5.257 \mathrm{a} \\
5.942 \mathrm{a} \\
6.0894\end{array}$ & $\begin{array}{l}-0.165 a \\
-0.144 a \\
-0.112 b\end{array}$ & $\begin{array}{l}31.2 \\
66.4 \\
37.9\end{array}$ & $\begin{array}{r}59.5 \\
268.6 \\
144.9\end{array}$ & $\begin{array}{l}86.9 \\
71.4 \\
85.0\end{array}$ & $\begin{array}{l}\mathbf{E} \\
\mathbf{E} \\
\mathbf{E}\end{array}$ \\
\hline Sapling & $\begin{array}{l}74 \\
76 \\
81\end{array}$ & $\begin{array}{l}15 \\
24 \\
15\end{array}$ & $\begin{array}{l}4.743 a \\
5.912 b \\
6.018 b\end{array}$ & $\begin{array}{r}-0.114 a \\
-0.147 a \\
-0.101 a\end{array}$ & $\begin{array}{l}36.4 \\
91.4 \\
83.1\end{array}$ & $\begin{array}{r}63.5 \\
131.0 \\
176.3\end{array}$ & $\begin{array}{l}70.4 \\
72.5 \\
70.3\end{array}$ & $\begin{array}{l}\mathbf{E} \\
\mathbf{E} \\
\mathbf{E}\end{array}$ \\
\hline Pole & $\begin{array}{l}74 \\
76 \\
81\end{array}$ & $\begin{array}{l}15 \\
24 \\
15\end{array}$ & $\begin{array}{r}349.3^{4} \\
1136.1 \mathrm{a} \\
1244.3 \mathrm{a}\end{array}$ & $\begin{array}{r}-8.1 a \\
-26.8 b \\
-29.8 b\end{array}$ & $\begin{array}{l}101.9 \\
365.5 \\
180.5\end{array}$ & $\begin{array}{l}234.6 \\
720.4 \\
734.5\end{array}$ & $\begin{array}{l}52.6 \\
39.7 \\
85.4\end{array}$ & $\begin{array}{l}\mathbf{L} \\
\mathbf{L} \\
\mathbf{L}\end{array}$ \\
\hline Sapling & $\begin{array}{l}74 \\
76 \\
81\end{array}$ & $\begin{array}{l}15 \\
24 \\
15\end{array}$ & $\begin{array}{l}5.878 a \\
7.139 b \\
6.972 b\end{array}$ & $\begin{array}{r}-0.058 a \\
-0.053 a \\
-0.052 a\end{array}$ & $\begin{array}{l}132.4 \\
478.7 \\
438.1\end{array}$ & $\begin{array}{l}242.8 \\
869.7 \\
682.5\end{array}$ & $\begin{array}{l}52.7 \\
27.0 \\
43.4\end{array}$ & $\begin{array}{l}\mathbf{E} \\
\mathbf{E} \\
\mathbf{E}\end{array}$ \\
\hline Pole & $\begin{array}{l}74 \\
76 \\
81\end{array}$ & $\begin{array}{l}15 \\
24 \\
15\end{array}$ & $\begin{array}{r}801.6^{4} \\
1839.5 \mathrm{a} \\
2229.0 \mathrm{a}\end{array}$ & $\begin{array}{l}-24.4 a \\
-52.3 b \\
-60.5 b\end{array}$ & $\begin{array}{l}173.8 \\
323.6 \\
289.2\end{array}$ & $\begin{array}{r}457.1 \\
1167.8 \\
1195.1\end{array}$ & $\begin{array}{l}77.4 \\
76.3 \\
90.4\end{array}$ & $\begin{array}{l}\mathbf{L} \\
\mathbf{L} \\
\mathbf{L}\end{array}$ \\
\hline Sapling & $\begin{array}{l}74 \\
76 \\
81 \\
\end{array}$ & $\begin{array}{l}15 \\
24 \\
15\end{array}$ & $\begin{array}{l}1102.64 \\
2233.8 \mathrm{a} \\
2540.9 \mathrm{a}\end{array}$ & $\begin{array}{r}-41.9 \mathbf{a} \\
-73.8 \mathbf{b} \\
-79.7 \mathbf{b}\end{array}$ & $\begin{array}{l}234.7 \\
436.9 \\
443.5\end{array}$ & $\begin{array}{r}638.6 \\
1362.9 \\
1456.4\end{array}$ & $\begin{array}{l}75.6 \\
66.4 \\
79.9 \\
\end{array}$ & $\begin{array}{l}\mathbf{L} \\
\mathbf{L} \\
\mathbf{L}\end{array}$ \\
\hline
\end{tabular}

in = sample size.

$2 \mathrm{E}=$ exponential and $\mathrm{L}=$ linear equations.

$3 \mathrm{and} b$ values in columns followed by the same letter are not significantly different $(P>0.05)$ within tree size class and vegetation category.

Not included in test because $b$ is significantly different.

sSE for log transformed models were estimated from residuals computed from untransformed data. 
Forbs growing under sapling-sized ponderosa pine trees generally responded with greater production than forbs in pole stands, except within clearcuts (Table 1). The number of species, however, followed the same general pattern noted in pole-sized stands (Table 2). Western yarrow was the dominant forb in clearcuts, producing from $24-42 \%$ of total forb aboveground biomass. This species shared dominance with cream peavine in GSLs of 5 and 9; but in all sapling-sized pine stands stocked at higher levels, cream peavine was dominant, accounting for 32 to $58 \%$ of the forb production.

Shrub production varied greatly among GSLs in sapling stands (Table 1). The number of shrub species among GSLs was similar (Table 2). However, bearberry was clearly dominant in all GSLs producing from 75-99\% of current annual shrub growth.

Total production in sapling-sized ponderosa pine stands was lower in 1974 than in either 1976 or 1981 across all GSLs, while latter years were similar. Least forage was produced in GSL 28 and unthinned sapling stands (Table 1). Generally, total production was similar between sapling-and pole-sized pine stands, except in in unthinned stands.

\section{Overstory-Understory Relationships}

Of the equations tested to describe relationships between understory production and basal area of ponderosa pine, the linear $(\mathrm{Y}=\mathrm{a}+\mathrm{bX})$ and exponential $\left(\mathrm{Y}=\mathrm{e}^{\mathrm{a}+\mathrm{bx}}\right)$ forms yielded best results as indicated by $R^{2}$ values. More complicated nonlinear forms did not offer significant improvement over the linear or exponential models. Generally, graminoid and forb relationships were best described by the exponential, shrubs were variable, and total forage production best described by the linear model (Tables 3 and 4). T-tests of slope coefficients (b) revealed all were different from 0 , indicating that understory production responded significantly to changes in ponderosa pine stocking levels as measured by basal areas.

Generally, when testing the hypothesis that slopes for years within stand/vegetation class were homogeneous, no significant differences were noted among b values for graminoids and forbs. The only exception was in pole stands during 1981, where forb production decreased significantly less with increasing basal areas than it did in 1974 or 1976 (Table 3). Shrub production under pole stands and total production under both sapling and pole stands did demonstrate consistencies. Slope (b) values in all 3 of these cases were lower for 1974 (Table 3 ). This indicates the rate of decrease in pole stand shrub production and total production in both-size classes of ponderosa pine resulting from increases in basal area was significantly faster in 1976 and 1981 than in 1974 when the least forage was produced. The same general relationship held when data from stands were combined (Table 4), but only for total production.

In cases where slopes were determined to be homogeneous, further testing revealed some significant differences among intercepts (a) (Table 3). Graminoids had significantly higher intercepts in 1981 in both sapling and pole stands. Further, intercepts were not different for total production in pole and sapling stands for 1976 and 1981 . However, 1974 could not be included in the latter analysis, because respective slope values for pole and sapling

Table 4. Coefficients (a and b), standard error of the estimate (SE), mean of dependent variables (Ÿ), and coefincients of determination ( $\left.R^{2}\right)$ deseribing relationships between understory production (Y) and ponderoan pine basal area $(X)$ when pole- and sapling-sized stands are combined, when years are combined, and when stands and years are combined in the Black Hills, South Dakota.

\begin{tabular}{|c|c|c|c|c|c|c|c|c|}
\hline Veg. class & Year/stand & $\mathrm{n}^{1}$ & a & b & SE & $\overline{\mathbf{Y}}$ & $R^{2}$ & Type \\
\hline Graminoids & $\begin{array}{l}74 \\
76 \\
81\end{array}$ & $\begin{array}{l}30 \\
48 \\
30\end{array}$ & $\begin{array}{l}6.251 \mathrm{a}^{3} \\
6.601 \mathrm{a} \\
7.216 \mathrm{~b}\end{array}$ & $\begin{array}{l}-.-S t a n \\
-0.141 a^{3} \\
-0.124 a \\
-0.137 a\end{array}$ & $\begin{array}{l}\text { mbined- } \\
205.1^{4} \\
177.7 \\
277.3\end{array}$ & $\begin{array}{l}262.3 \\
277.4 \\
456.3\end{array}$ & $\begin{array}{l}76.0 \\
74.2 \\
81.5\end{array}$ & $\begin{array}{l}\mathbf{E} \\
\mathbf{E} \\
\mathbf{E}\end{array}$ \\
\hline Forbs & $\begin{array}{l}74 \\
76 \\
81\end{array}$ & $\begin{array}{l}30 \\
48 \\
30\end{array}$ & $\begin{array}{l}4.841 \mathrm{a} \\
5.806 \mathrm{~b} \\
6.083 \mathrm{c}\end{array}$ & $\begin{array}{l}-0.118 a \\
-0.135 a \\
-0.110 a\end{array}$ & $\begin{array}{l}31.7 \\
80.1 \\
65.7\end{array}$ & $\begin{array}{r}61.5 \\
120.6 \\
160.1\end{array}$ & $\begin{array}{l}81.2 \\
75.5 \\
79.9\end{array}$ & $\begin{array}{l}\mathbf{E} \\
\mathbf{E} \\
\mathbf{E}\end{array}$ \\
\hline Shrubs & $\begin{array}{l}74 \\
76 \\
81\end{array}$ & $\begin{array}{l}30 \\
48 \\
30\end{array}$ & $\begin{array}{l}5.908 \mathrm{a} \\
7.248 \mathrm{~b} \\
7.371 \mathrm{~b}\end{array}$ & $\begin{array}{l}-0.053 a \\
-0.062 a \\
-0.080 a\end{array}$ & $\begin{array}{l}118.0 \\
464.0 \\
459.1\end{array}$ & $\begin{array}{l}238.4 \\
811.6 \\
708.3\end{array}$ & $\begin{array}{l}52.1 \\
37.9 \\
60.9\end{array}$ & $\begin{array}{l}\mathbf{E} \\
\mathbf{E} \\
\mathbf{E}\end{array}$ \\
\hline Total & $\begin{array}{l}74 \\
76 \\
81\end{array}$ & $\begin{array}{l}30 \\
48 \\
30\end{array}$ & $\begin{array}{c}947.3^{5} \\
2031.4 a \\
2364.6 a\end{array}$ & $\begin{array}{l}-31.4 a \\
-61.2 b \\
-67.7 b\end{array}$ & $\begin{array}{l}225.5 \\
392.8 \\
379.2\end{array}$ & $\begin{array}{r}562.8 \\
1209.6 \\
1325.7\end{array}$ & $\begin{array}{l}71.6 \\
69.9 \\
83.5\end{array}$ & $\begin{array}{l}\mathbf{L} \\
\mathbf{L} \\
\mathbf{L}\end{array}$ \\
\hline Graminoids & $\begin{array}{c}\text { Pole } \\
\text { Sapling }\end{array}$ & $\begin{array}{l}54 \\
54\end{array}$ & $\begin{array}{l}6.318 \\
6.811 b\end{array}$ & $\begin{array}{l}-0.132 a \\
-0.125 a\end{array}$ & $\begin{array}{l}158.3 \\
275.0\end{array}$ & $\begin{array}{l}231.5 \\
426.9\end{array}$ & $\begin{array}{l}74.9 \\
60.2\end{array}$ & $\begin{array}{l}\mathbf{E} \\
\mathbf{E}\end{array}$ \\
\hline Forbs & $\begin{array}{c}\text { Pole } \\
\text { Sapling }\end{array}$ & $\begin{array}{l}54 \\
54\end{array}$ & $\begin{array}{l}5.259 \mathrm{a} \\
5.445 \mathrm{a}\end{array}$ & $\begin{array}{l}-0.128 a \\
-0.108 a\end{array}$ & $\begin{array}{l}83.3 \\
45.1\end{array}$ & $\begin{array}{r}83.5 \\
125.4\end{array}$ & $\begin{array}{l}76.3 \\
51.7\end{array}$ & $\begin{array}{l}\mathbf{E} \\
\mathbf{E}\end{array}$ \\
\hline Shrubs & $\begin{array}{c}\text { Pole } \\
\text { Sapling }\end{array}$ & $\begin{array}{l}54 \\
54\end{array}$ & $\begin{array}{l}6.646 a \\
6.673 a\end{array}$ & $\begin{array}{r}-0.081 a \\
-0.048 a\end{array}$ & $\begin{array}{l}428.9 \\
476.2\end{array}$ & $\begin{array}{l}452.5 \\
643.2\end{array}$ & $\begin{array}{l}35.6 \\
21.3\end{array}$ & $\begin{array}{l}\mathbf{E} \\
\mathbf{E}\end{array}$ \\
\hline Totals & $\begin{array}{c}\text { Pole } \\
\text { Sapling }\end{array}$ & $\begin{array}{l}54 \\
54\end{array}$ & $\begin{array}{l}7.608^{5} \\
7.675\end{array}$ & $\begin{array}{l}-0.120 \mathrm{a} \\
-0.078 \mathrm{~b}\end{array}$ & $\begin{array}{l}551.3 \\
613.9\end{array}$ & $\begin{array}{r}767.2 \\
1195.6\end{array}$ & $\begin{array}{l}62.9 \\
56.3\end{array}$ & $\begin{array}{l}\mathbf{E} \\
\mathbf{E}\end{array}$ \\
\hline $\begin{array}{l}\text { Graminoids } \\
\text { Forbs } \\
\text { Shrubs } \\
\text { Total }\end{array}$ & $\begin{array}{l}- \\
- \\
-\end{array}$ & $\begin{array}{l}108 \\
108 \\
108 \\
108\end{array}$ & $\begin{array}{l}6.680 \\
5.483 \\
7.016 \\
7.843\end{array}$ & $\begin{array}{c}\text {-Stands a } \\
-0.134 a \\
-0.120 a \\
-0.081 b \\
-0.103 b\end{array}$ & $\begin{array}{c}\text { ars com } \\
233.9 \\
88.1 \\
485.0 \\
648.6\end{array}$ & $\begin{array}{r}323.2 \\
113.4 \\
616.2 \\
1055.2 \\
\end{array}$ & $\begin{array}{l}72.2 \\
65.0 \\
38.0 \\
56.4\end{array}$ & $\begin{array}{l}\mathbf{E} \\
\mathbf{E} \\
\mathbf{E} \\
\mathbf{E}\end{array}$ \\
\hline
\end{tabular}

in = sample size.

${ }^{2} \mathrm{E}=$ exponential and $\mathrm{L}=$ linear equations.

3 a and b values in columns followed by same letter are not significantly different $(P>0.05)$ within vegetation class for stands combined and years combined and among vegetation classes for stands and years combined.

"Not included in test because $b$ is significantly different.

sSEs for log transformed models were estimated from residuals computed from untransformed data. 
stands were significantly different from the others. Shrub production intercepts also were similar between size-class stands for 1976 and 1981. Intercepts for forb production were lowest for 1974 in both pole and sapling stands; but these differences were significant only in sapling stands.

When stands were combined, no differences were noted in b values among years within vegetation class. The slope for total production, however, was significantly flatter for the driest year, 1974, than for 1976 or 1981 (Tables 4 and 5). Intercepts were significantly different among years, but with no consistent pattern among vegetation classes; for graminoids they were significantly lower in 1974 and 1976 than in 1981 . For forbs, all years were different, and for shrubs, 1974 intercepts were lower than for either of the other 2 years.

Combining years resulted in differences in $b$ values for sapling stands and pole stands, but, again, only for total production (Table 4). As basal area increased, total understory production in pole stands decreased significantly faster than under sapling stands. Combining years resulted in more consistent relationships between pole and sapling stand intercepts for forbs and shrubs; but sapling stands had a significantly higher graminoid intercept than did pole stands. When data for stands and years were analyzed together, slope values for graminoid and forb production were higher than those for shrubs or total production (Table 4); this indicates that as basal area increased herbaceous production decreased at a faster rate than did shrub or total production.

Standard errors (SEs) of the estimate appeared lower when stands and years were analyzed separately (Table 3) than when either or both were combined (Table 4). Lowest SEs, relative to the mean of dependent variables $(Y)$, were noted for total production. Here SEs ranged from $24-38 \%$ of the mean when stands and years were analyzed separately. They were only slightly greater when stands were combined ( 29 to $40 \%$ ) but increased markedly when years ( 51 to $72 \%$ ) and years and stands $(61 \%)$ were combined. The same general pattern held for grasses, forbs, and shrubs except that variability was slightly greater between cases where stands and years were separated as compared to stands combined.

When analyses were separate (Table 3), SEs/Y indicate less variability in pole than in sapling stands. Differences in variability among years were more inconsistent; no patterns were apparent.

Coefficients of determination $\left(\boldsymbol{R}^{2}\right)$ for graminoids, forbs, and total understory production ranged from $65-90 \%$ (Table 3 ). $R^{2}$ values for shrub production were noticeably lower, ranging from $27-85 \%$. With the exception of one value all $\boldsymbol{R}^{2}$ for shrubs were less than $53 \%$.

Combining stands did not unduly affect the amount of variation in understory as explained by changes in overstory. Graminoid, forb, and total understory production $R^{2}$ values ranged from $72-84 \%$, while shrub values remained low, ranging from 38-61\% (Table 4). When years were combined and stands and years combined, $R^{2}$ values declined, ranging from $52-76 \%$ for graminoid, forb, and total production and from $21-38 \%$ for shrub production (Table 4).

\section{Discussion and Management Implications}

As tree density increases, understory production decreases (Clary 1975, Ffolliott and Clary 1982, Bartlett and Betters 1983). Understory production for both pole and sapling stands in the Black Hills was no exception. Generally, trends for understory production were higher for graminoids, forbs, and shrubs under saplings. Species diversity also was greater in sapling stands and decreased in both sapling and pole stands as GSLs increased. Livestock grazing was not considered an influencing factor on understory production or species diversity. Stocking rates were light at 11 ha/AUM and grazing was primarily confined to the meadows. All study sites were located away from meadows at higher elevations.

Relationships between tree density and understory production are affected by timber management. Clearcuts to $9 \mathrm{~m}^{2} / \mathrm{ha}$ basal area yielded the greatest production of understory in both pole and sapling stands. Overall, averaged across stands, plant production decreased approximately $37 \%$ at $5 \mathrm{~m}^{2} /$ ha basal area compared to clearcuts. At a $14 \mathrm{~m}^{2} /$ ha basal area, total understory production decreased approximately $76 \%$, and species diversity decreased approximately $32 \%$ relative to clearcuts.

The relationships between tree size class and grass species composition were not clear, but may be related to microclimate. Timber oatgrass was abundant in old stands and sparse in sapling stands, and roughleaf ricegrass was common in sapling stands and limited under poles. Timber oatgrass generally is more abundant in moist sites (McGregor 1986). Sapling stands, (represented by more stems-per-unit area than pole stands on sites with equal basal area), may have a slightly more moist microclimate. Sapling stands also tended to have more total understory production.

Understory production was more predictable with curvilinear models using basal area of trees as the independent variable. Others have found similar relationships in ponderosa pine (Clary and Ffolliott 1966, Pase 1958, Pase and Hurd 1957, Jameson 1967, Clary et al. 1975). Linear relationships in this study were found for total understory production by years, total production with stands combined, and for shrubs only in pole stands. McConnell and Smith (1965) also reported linear relationships between understory and ponderosa pine overstory.

Livestock grazing is a major use of many forested lands along with timber production. The potential for livestock forage production was maximized on clearcuts and decreased about $60 \%$ at pine stocking levels of $9 \mathrm{~m}^{2} / \mathrm{ha}$. Clary et al. (1975) reported that forage and sawlog production both would be maximized in pine stands having a basal area of 10 to $14 \mathrm{~m}^{2} /$ ha. Understory and tree production was maximum in Black Hills ponderosa pine when basal area was $14 \mathrm{~m}^{2}$ / ha (Severson and Boldt 1977).

Forage classes used by cattle grazing Black Hills ponderosa pine ranges were, in decreasing order, graminoids, shrubs and trees, and forbs (Uresk and Lowry 1984, Uresk and Paintner 1985). Major graminoids included sedges and wheatgrasses. Timber oatgrass was common in cattle diets (7-8\%); ricegrass was less abundant $(<1 \%$ ). White clover (Trifolium repens) was the major forb; snowberry and Oregon grape were preferred shrubs. Forage provided from sapling and pole stands would be similar. Although the more consumed timber oatgrass is more abundant in pole stands and the less consumed roughleaf ricegrass dominates sapling stands, the diversity of other species, especially at the lower GSLs, negates this difference.

Interspersion of clearcuts, especially on less productive sites, would beneficially increase forage production for both wild and domestic species (Reynolds 1969, Miller and Krueger 1976, Thompson and Gartner 1971). Management programs can be made flexible by judicious placement of clearcuts along with precommercial and commercial tree-thinning programs, provided that cover requirements for wild species are not ignored (Severson and Medina 1983).

White-tailed deer (Odocoileus virginianus) are important herbivores in Black Hills pine forests. They are primarily browsers but grasses and forbs are seasonally important (Schneeweis et al. 1972, Schenck et al. 1972, Dietz et al. 1979). Shrub production is relatively high at stocking levels below $14 \mathrm{~m}^{2} / \mathrm{ha}$, but most productive is bearberry, a prostrate evergreen shrub that is not available in winter because of snow depths. However, it is an important fall and early winter food. Therefore, thinning to a basal area of less than 14 $\mathrm{m}^{2} /$ ha may increase browse production. 
Thinning pine also reduces loss of tree stands to beetles and other insects (Bartos and Amman 1989). The microclimate apparently is altered enough in thinned stands to interfere with beetle activity. Indications are that pheromone plumes, which disrupt beetle attack, are affected.

Standard errors of the estimate, relative to the mean of dependent variables, indicate that total forage production can be estimated reasonably with models developed for pole and sapling stands separately or when they are combined. Similar but somewhat less precise estimates could be expected for the individual forage categories-graminoids, forbs, and shrubs. Low $R^{2}$ for shrubs, however, indicate that caution should be used in interpreting results for this particular group.

Variability within years appears to be within acceptable limits for predictive modeling. When years are combined, either within stands or among stands, SEs/Y increase markedly, which indicates a less reliable model for estimating plant production on individual sites. However, the models provide reliable estimates when predicting herbage means as related to tree basal areas. Managers are primarily interested in herbage means for estimating livestock and wildlife use. General estimates of carrying capacity of both livestock and wildlife can be estimated from the predicted herbage values.

Increasing SEs/ $Y$ when years are combined indicates there is considerable variation among years. This was partially attributed to differences in precipitation; 1974 had about one-half the growing season precipitation of 1976 and 1981 each. Differences in intercepts among years were not consistent with these moisture patterns, however, which means understory production is affected not only by total growing season moisture but also by other factors (e.g., intensity, patterns within season, temperatures, etc.). If these factors can be identified, they could be used to develop complex models that might facilitate more precise predictions over years. However more than 3 years of data would be needed to address this problem.

\section{Literature Cited}

Bartlett, E.T., and D.R. Betters, eds. 1983. Overstory-understory relationships in western forests. Western Reg. Res. Pub. 1, Colorado State Univ., Fort Collins.

Bartos, D.L., and G.D. Amman. 1989. Microclimate: an alternative to tree vigor as a basis for mountain pine beetle infestations. Res. Pap. INT-400. Ogden, UT: U.S. Department of Agriculture, Forest Service, Intermountain Research Station.

Bennett, D.L., G.D. Lemme, and P.D. Evenson. 1987. Understory herbage production of major soils within the Black Hills of South Dakota. J. Range Manage. 40:166-170.

Boldt, C.E., R.R. Alexander, and M.J. Larson. 1983. Interior ponderosa pine in the Black Hills. p. 80-83. In: Silviculture systems for the major forest types of the United States. USDA Forest Serv. Handbook 445. R.M. Burns, Tech. Comp. USDA, Washington, D.C.

Clary, W.P., and P.F. Ffolliott. 1966. Differences in herbage-timber relationships bet ween thinned and unthinned ponderosa pine stands. USDA Forest Serv. Res. Note RM-74. Rocky Mtn. Forest and Range Exp. Sta., Fort Collins, Colo.

Clary, W.P. 1975. Range management and its ecological basis in the ponderosa pine type of Arizona: The status of our knowledge. USDA Forest Serv. Res. Pap. RM-158. Rocky Mtn. Forest and Range Exp. Sta., Fort Collins, Colo.
Clary, W.P., W.H. Kruse, and F.R. Larson. 1975. Cattle grazing and wood production with different basal areas of ponderosa pine. J. Range Manage. 28:434-437.

Currie, P.0. 1975. Grazing management of ponderosa pine-bunchgrass ranges of the central Rocky Mountains: The status of our knowledge. USDA Forest Serv. Res. Pap. RM-159. Rocky Mtn. Forest and Range Exp. Sta., Fort Collins, Colo.

Dietz, D.R., D.W. Uresk, and H.E. Mesener. 1979. Deer habitat studies in the Black Hills: A summary report. Abstracts 32nd Annual Meeting, Society for Range Management, Casper, Wyoming.

Ffolliott, P.F., and W.P. Clary. 1982. Understory-overstory vegetation relationships: An annotated bibliography. USDA Forest Serv. Gen. Tech. Rep. INT-136. Intermtn. Forest and Range Exp. Sta., Ogden, Utah.

Graybill, F.A. 1976. Theory and application of the linear model. Duxbury Press, North Scituate, Mass.

Jameson, D.R. 1967. The relationship of tree overstory and herbaceous understory vegetation. J. Range Manage. 20:247-249.

McConnell, B.R., and J.G. Smith. 1965. Understory response three years after thinning pine. J. Range Manage. 18:129-132.

MeConnell, B.R., and J.G. Smith. 1970. Response of understory vegetation to ponderosa pine thinning in eastern Washington. J. Range Manage. 23:208-212.

MeGregor, R.L. (Coord.) 1986. Flora of the Great Plains. Univ. Press of Kansas, Lawrence.

Miller, R.F., and W.C. Krueger. 1976. Cattle use on summer foothill rangelands in northeastern Oregon. J. Range Manage. 29:367-371.

Miliken, G.A., and D.E. Johnson. 1984. Analysis of messy data. Vol. 1: Designed experiments. Lifetime Learning Publications, Belmont, Calif.

Pase, C.P. 1958. Herbage production and composition under immature ponderosa pine stands in the Black Hills. J. Range Manage. 11:238-243.

Pase, C.P., and R.M. Hurd. 1957. Understory vegetation as related to basal area, crown cover, and litter produced by immature ponderosa pine stands in the Black Hills. p. 156-158. In: Proc. Soc. Amer. Forest.

Reynolds, H.G. 1969. Improvement of deer habitat on southwestern forest lands. J. Forest. 67:803-805.

Schenck, T.E., III, R.L. Linder, and A.H. Richardson. 1972. Food habits of deer in the Black Hills, Part II: Southern Black Hills. So. Dak. Agr. Exp. Sta. Bull. 606. So. Dak. State Univ., Brookings.

Schneeweis, J.C., K.E. Severson, and L.E. Petersen. 1972. Food habits of deer in the Black Hills, Part I: Northern Black Hills. So. Dak. Agr. Exp. Sta. Bull. 606. So. Dak. State Univ., Brookings.

Severson, K.E., and C.E. Boldt. 1977. Options for Black Hills forest owners: Timber, forage, or both. Rangeman's J. 4:13-15.

Severson, K.E., and A.L. Medina. 1983. Deer and elk habitat management in the Southwest. J. Range Manage. Monogr. 2.

Severson, K.E., and J.F. Thilenius. 1976. Classification of quaking aspen stands in the Black Hills and Bear Lodge Mountains. USDA Forest Serv. Res. Pap. RM-166. Rocky Mtn. Forest and Range Exp. Sta., Fort Collins, Colo.

Statistical Graphics Corporation. 1986. Statgraphics Statistical Graphics System. 2115 E. Jefferson St., Rockville, Md.

Thilenius, J.F. 1972. Classification of deer habitat in the ponderosa pine forest of the Black Hills, South Dakota. USDA Forest Serv. Res. Pap. RM-91. Rocky Mtn. Forest and Range Exp. Sta., Fort Collins, Colo.

Thompson, W.W., and F.R. Gartner. 1971. Native forage response to clearing low quality ponderosa pine. J. Range Manage. 24:272-277.

Uresk, D.W., and D.G. Lowrey. 1984. Cattle diets in the central Black Hills of South Dakota. In: Symposium proceedings on wooded draws. D.L. Noble and R.P. Winokur, eds. Great Plains Agr. Counc. Pub. 111.

Ureak, D.W., and W.W. Paintner. 1985. Cattle diets in a ponderosa pine forest in the northern Black Hills. J. Range Manage. 38:440-442.

USDA Foreat Service, nd. Land and resource management plan: Black Hills National Forest, Custer, S. Dak. 